\title{
AS POLÍTICAS DE EDUCAÇÃO POPULAR EM NATAL-RN (1957-1964)
}

\author{
W. P. BARBOSA JUNIOR \\ Instituto Federal de Educação, Ciência e Tecnologia do Rio Grande do Norte \\ walterjrnatal@hotmail.com
}

Artigo submetido em março/2016 e aceito em março/2016

DOI: $10.15628 /$ holos.2016.4179

\section{RESUMO}

Este artigo analisa as políticas de educação no município de Natal, Rio Grande do Norte, entre os anos de 1957 e 1964. Ao mesmo tempo busca uma reflexão sobre os modos como tais políticas foram elaboradas e executadas pela Prefeitura Municipal de Natal numa perspectiva da Educação Popular. Assumimos uma abordagem qualitativa, contemplando análise documental, bibliográfica, utilizando elementos do paradigma indiciário no viés da História Cultural. A pesquisa evidenciou que o processo histórico existenciado em várias dimensões pela sociedade natalense, em meados do século $X X$, floresceu a partir de três raízes: a) participação e diálogo entre a prefeitura e a população natalense; b) construção e reconstrução das práticas pedagógicas priorizando, em seus programas de ação, a alfabetização para todos; c) democratização da cultura. Essas raízes transformaram a Cidade de Natal, durante os sete anos da administração Djalma Maranhão em uma cidade educadora e as políticas educacionais elaboradas e executadas pela equipe dessa gestão em políticas de educação popular.

PALAVRAS-CHAVE: Políticas educacionais, Educação popular, Cidade educadora, Djalma Maranhão.

\section{THE POPULAR EDUCATION POLICIES IN NATAL-RN (1957-1964)}

\begin{abstract}
This article analyzes education policies in Natal, Rio Grande do Norte, from 1957 to 1964 . At the same time it seeks to reflect on how these policies were developed and executed by the City Hall of Natal within a perspective of Popular Education. We used a qualitative approach, looking on a documentary, bibliographical analysis, using elements of the evidentiary paradigm on the bias of Cultural History. The research indicated that the historical process experienced in various dimensions within Natal's society in the mid-twentieth century,
\end{abstract}

flourished from three roots: a) participation and dialogue between the City Hall and the population in Natal; b) construction and reconstruction of pedagogical practices prioritizing, in the action programs, literacy for all; c) democratization of culture. Those roots transformed Natal-RN during the seven years of Djalma Maranhão's administration in an educating city, and the educational policies created and executed by the management in popular education policies team

KEYWORDS: Educational policies, popular education, educating City, Djalma Maranhão. 


\section{SINALIZANDO OS CAMINHOS DA PESQUISA}

As políticas de educação popular do município de Natal, Rio Grande do Norte, nos anos de 1957 a 1964, apresentam peculiaridades que nos convidam a análises importantes sobre o processo histórico educacional brasileiro. Entendemos as políticas municipais como um conjunto de ações pensadas, elaboradas, estruturadas e executadas pelo governo municipal com o fim de implementar os programas de governo considerando as necessidades da cidade e da população. Em Natal estas ações ganharam uma dimensão educacional popular na medida em que sua meta era alfabetizar todas as crianças em idade escolar e todos os adultos analfabetos da cidade.

Como nosso objetivo era buscar quais as políticas de educação elaboradas e implementadas pela Prefeitura Municipal de Natal entre os anos de 1957 a 1964 procuramos durante a pesquisa, uma abordagem que nos aproximasse da realidade vivida. Com o objetivo de identificar e analisar as políticas de educação popular, elaboradas e executadas pela Prefeitura Municipal de Natal nos referidos anos, uma pesquisa qualitativa, que contemplasse análise documental e bibliográfica, com uma abordagem político-filosófica, foi o caminho escolhido.

A busca pelos dados históricos foi pensada a partir de um método, de um tempo delimitado e uma questão norteadora: Quais as políticas de educação elaboradas e implementadas pela Prefeitura Municipal de Natal nos anos de 1957 a 1964? Tendo esse questionamento como fio condutor, passamos à caracterização do tempo, numa delimitação histórica, educacional e cultural, cuja contextualização nos permitiram visualizar melhor os indícios que buscávamos para nossas análises futuras. O período em investigação- 1957 e 1962 - foi estabelecido a partir de dois marcos histórico: 1) 1957 foi marcado pela regulamentação da Lei Municipal no 648, que cria a Diretoria de Ensino Municipal, base para muitas das ações populares-educacionais em Natal; 2) 1964 foi o ano quando, com a Ditadura Civil e Militar, foi interrompida a política de educação popular em Natal.

Nesta direção elegemos duas categorias de análise: educação popular e consciência. Categorias que se harmonizam no contexto, na medida em que se coadunam contribuindo para um processo efetivo de desalienação e consequente libertação e transformação da sociedade. Assumimos, nesta pesquisa, o conceito de Educação Popular a partir de Góes (2002, p. 1-2), entendida como universalização da escola. A consciência é definida para nós, com base em Freire (1980), partindo de suas considerações sobre a passagem da fase de transição de uma consciência transitivo-ingênua para a consciência transitivo-crítica, na consolidação de uma educação crítica, conscientizadora e fundamentada nos princípios da liberdade e do diálogo. (FREIRE, 2011, p. 84).

O próximo passo na direção de uma metodologia válida ao objeto delimitado foi buscar um método. A abordagem de Ginzburg em Os andarilhos do bem (2007) e O queijo e os vermes (2006) foi a inspiração para buscarmos nas fontes uma trilha de informações que permitissem uma aproximação da realidade investigada. O Paradigma Indiciário de Ginzburg (1989) foi nesta investigação método em um conjunto de procedimentos que orientaram a análise dos indícios, dos sinais e dos dados, em um cuidado investigativo no qual os pormenores de uma situação são identificados, possibilitando uma aproximação mais rigorosa dos aspectos que constituem o objeto de estudo. 
Investigamos a materialidade do contexto por meio de entrevistas com os protagonistas desta história, nos documentos oficiais, figuras, leis e textos. Os documentos oficiais utilizados pertencem ao acervo do Instituto Histórico e Geográfico do Rio Grande do Norte (IHGRN) e ao Arquivo Público Municipal de Natal. As fontes de pesquisas impressas e/ou figuras representam as vivências da cidade registrando, em dados históricos, um período da educação municipal.

Optamos por entrevistar três pessoas que experienciaram os fatos relacionados com a educação popular do período em estudo: a professora que, atualmente, trabalha na Secretaria Municipal de Educação Hortência Maria Freire da Costa Advíncula, professora na Campanha De Pé no Chão Também se Aprende a Ler; o diretor do ensino municipal, em 1961, Omar Fernandes Pimenta, que implantou as Escolinhas em Natal, e com o senhor Luiz Matias da Silva, integrante do Grupo de Dança Araruna, no ano de 1962.

A mídia impressa foi fundamental para encontrarmos os indícios dessa cidade educadora. Tivemos acesso à Folha da Tarde e Jornal de Natal dos anos de 1957 a 1962 disponíveis no Instituto Histórico e Geográfico do Rio Grande do Norte (IHGRN). Procuramos ampliar as fontes estudadas com o trabalho de identificação, leitura e problematização das pesquisas feitas no contexto do Programa de Pós-Graduação em Educação da Universidade Federal do Rio Grande do Norte, que abordaram temas, ou que tiveram, como foco de suas pesquisas, os períodos pertinentes ao objeto de nossa dissertação, como os trabalhos de Ribeiro (2008), As Praças da Cultura no Governo Djalma Maranhão (1960-1964), Leite (2008), Em nome da ordem: a Prefeitura Municipal de Natal como espaço da subversão.

A análise dos documentos oficiais supôs a realização de leituras fundamentadas em conceitos científicos e numa abordagem teórica político-filosófica. Com fulcro nas contribuições de Aristóteles (2011), buscamos suas considerações sobre o homem como animal político e legislador, tendo a cidade por objeto e a virtude do cidadão relacionada com a sua atuação na política. Refletimos sobre as ideias de Hobbes (2009) e suas considerações sobre, poder, Estado, acordos e pactos. Governar bem, para esse filósofo, é constituir um Estado sobre bases sólidas, forte, durável, sendo impossível a sua dissolução. Considera o poder como um conjunto de meios empregados para obter uma aparente vantagem no futuro; e o desejo de obtê-lo só cessa com a morte. À luz das ideias de Hobbes, o Estado é definido como homem artificial - o Leviatã - sob três dimensões: a primeira, como uma multidão de homens reunidos; a segunda, como uma única pessoa representando os pactos contratados reciprocamente por muitos indivíduos; já na terceira dimensão a pessoa é representada pelos pactos da multidão, na qual se fez autor e pode usar a força para obter a paz e a defesa comum.

Dentre os teóricos eleitos para conceder suporte ao presente trabalho, adotamos, como referência-base, a literatura de autores do Rio Grande do Norte, representada na obra De Pé no Chão Também se Aprende a Ler (1961-64): uma escola democrática, do professor e Secretário de Educação em 1960, Professor Moacyr de Góes. Igualmente, na obra de Cortez (2005) Memórias da Campanha "De Pé no Chão Também se Aprende a Ler": reflexões sobre a prática pedagógica de ontem - cuja contribuição recaiu sobre a contextualização da formação docente dos professores leigos. 
Dialogando com Germano (1989), em Lendo e aprendendo: a campanha de pé no chão, encontramos o contexto da política de Natal sobre o período em estudo. Por sua vez, consideramos as reflexões de Galvão (2004), no livro 1964: Aconteceu em Abril, as narrativas dos protagonistas que trabalhavam na gestão da Secretaria Municipal de Educação e que foram indiciados e perseguidos pelo Golpe Civil e Militar de 1964.

As fontes permitiram perceber que toda a trajetória da educação popular se constituiu como um movimento que implantava instituições educativas como lugares de diálogos, discussões, reflexões, lugares de formação, de participação popular, de democratização da cultura e de produção de novos conhecimentos. O método permitiu que pudéssemos compreender como esse esforço educacional foi tornando Natal uma cidade educadora e em uma dimensão popular de educação.

\section{POLÍTICA DE EDUCAÇÃO POPULAR EM NATAL: PARTICIPAÇÃO E COMUNIDADE}

Entre as fontes verificadas para a elaboração desta pesquisa, buscamos na legislação municipal, a Lei no 648, de 9 de janeiro de 1957, que cria a Diretoria de Ensino Municipal e dá outras providências e a Lei no 988, de 19 de dezembro de 1959, que reorganiza os serviços administrativos da Prefeitura Municipal de Natal e dá outras providências. O estudo de todo esse ordenamento jurídico-educacional favoreceu o conhecimento das ideias, valores e normas vigentes no contexto social e educacional que direcionavam as práticas pedagógicas, a formação docente e a regulamentação da educação municipal nos anos de 1957 a 1964.

Mas esse ordenamento tem início um ano antes com a nomeação do Deputado Djalma Maranhão para a prefeitura da cidade de Natal-RN. Como era praxe no período em estudo sua nomeação foi feita pelo Governador do Estado, Dinarte de Medeiros Mariz, no ano de 1956. Este primeiro mandato de Djalma Maranhão, por meio de indicação, terminou em 1959 e ele mantevese no cargo, por meio do voto popular nos quatro anos seguintes, entre 1960-1964, quando foi deposto pelo Regime Militar.

Djalma Maranhão era jornalista e antes da vida política tinha sido instrutor de Educação Física da Escola Estadual Atheneu Norte-rio-grandense. Suas administrações foram marcadas pelos programas e campanhas em defesa de uma educação para todos, com metas definidas para erradicação do analfabetismo.

Assim, do primeiro mandato, entre 1956 e 1959 podemos destacar a criação das Escolinhas - salas de alfabetização destinadas a crianças, jovens e adultos - e, da segunda administração, no período compreendido entre 1960-1964, destacamos a organização das bibliotecas populares e as Praças de Cultura; sua meta prioritária de governo foi à erradicação do analfabetismo de crianças, jovens e adultos, como também a democratização da cultura.

Procedendo a uma investigação histórica, constatamos que Natal, durante os primeiros anos da década de 1960, caracterizava-se pela existência da pobreza e do desemprego. Em meio a tal realidade, a educação pública primária, registrava um número enorme de crianças, jovens e adultos analfabetos, tendo em vista o reduzido número de escolas (GÓES, 2000). A cidade estava imersa em um processo histórico que remontava décadas de exclusão escolar, os índices relativos 
ao analfabetismo no município - em relação à população acima de 14 anos de idade - apresentava um número significativamente elevado. Com uma população de 154.276 habitantes, o Censo de 1960, registrava, naquela época, em Natal, um quantitativo de 60.254 analfabetos, sendo 35.810 crianças e 24.444 adultos (GÓES, 1980). Esse alto índice de analfabetismo concorreu para que a população procedesse a reivindicações e se disponibilizasse a modificar essa realidade.

O Prefeito de Natal movimentava-se em duas frentes, por um lado, buscava criar parâmetros legais para a condução do processo educacional e, por outro, o Prefeito atuava criando as Escolinhas de alfabetização. Eram locais cedidos gratuitamente por instituições e particulares à Prefeitura. Tratava-se de salas de sindicatos, clubes, igrejas, cinemas e casas residenciais organizadas para ensinar a ler, escrever e contar. Essas Instituições Educativas eram destinadas às crianças e jovens que não frequentavam a escola. Essa foi a forma que a Prefeitura de Natal encontrou, naquele momento, para iniciar o processo de alfabetização, o que pode ser explicado pela ausência de recursos públicos para a construção de escolas. As Escolinhas foram implantadas por Omar Fernandes Pimenta e Ticiano Duarte (GÓES, 1980) como medida de curto prazo, com o objetivo de diminuir os altos índices de analfabetismo.

$\mathrm{Na}$ verdade, o procedimento seria - conforme ocorreu - possibilitar a participação da população no processo de educação, uma vez que as instituições e os moradores da cidade de Natal clamavam pela escolarização da população menos favorecida, estabelecendo um diálogo entre o poder público municipal e a população da cidade para encontrar alternativas que viabilizassem a educação popular para todos. Conforme podemos ver, a implantação das políticas municipais voltadas para a educação popular pressupôs e supôs uma diversidade de implicações, iniciativas, determinações, além de realizações empreendidas pelo então prefeito Djalma Maranhão, cujos auxiliares, sintonizados com as políticas por ele previstas, igualmente concorreram para que o ensino municipal fosse instituído.

Dentro dessa tensão entre criar leis e operacionalizar o processo educativo, percebemos no curso da nossa pesquisa que as primeiras iniciativas do prefeito Djalma Maranhão visando a uma estruturação educacional na cidade de Natal teve como marco inicial a Lei no 648, de 9 de janeiro de 1957, que cria a Diretoria de Ensino Municipal e dá outras providências. (LIVRO DE REGISTRO DO ARQUIVO PÚBLICO MUNICIPAL). Esta Lei foi constituída com onze artigos que regulamentaram o Ensino Público Municipal de Natal, a saber:

Art. $1^{\circ}$ - Fica criada a Diretoria de Ensino Municipal, diretamente subordinada à Secretaria de Negócios Internos e Jurídicos, e consequentemente o cargo de Diretor de Ensino Municipal, de provimento em comissão, incluindo a tabela II do Quadro Único da Prefeitura Municipal, criada pela Lei n. 197, de 31 de janeiro de 1953 e com vencimento mensal de $\mathrm{Cr} \$ 6.000,00$ (seis mil cruzeiros).

Parágrafo Único - A primeira nomeação, a critério do Prefeito, poderá ser feita em caráter efetivo, ficando seu titular dispensado de concurso.

Art. $2^{\circ}$. O Ensino Municipal é leigo e será ministrado a ambos os sexos, nele proibida quaisquer discriminações tendentes a lhe impedir ou dificultar o acesso.

Art. $3^{\circ}$. O ensino será registrado preferencialmente na periferia suburbana da cidade, e terá em vista promover a sua difusão nas camadas populares. 
Art. $4^{\circ}$. Para objetivar os seus fins, o Executivo Municipal criará e manterá, nos bairros e subúrbios da cidade e nas zonas rurais, grupos escolares e Escolas Municipais (Escolinhas).

Art. $5^{\circ}$. O ensino Municipal será inteiramente gratuito, nele proibida a cobrança de quaisquer taxas ou contribuições de quaisquer naturezas e sob qualquer pretexto.

Parágrafo Único - O disposto no presente artigo não exclui, porém, a criação de caixas escolares ou cooperativas.

Art. $6^{\circ}$. Fica ainda criado, para fiel cumprimento da presente lei, o cargo de Assessor Técnico da Diretoria de Ensino, incluído na Tabela II do Quadro Único da Prefeitura Municipal de Natal, de provimento em Comissão, com vencimento mensal de $\mathrm{Cr} \$ 4.300,00$.

Art. $7^{\circ}$. Fica o prefeito autorizado a conceder a gratificação mensal de $\mathrm{Cr} \$ 2.000,00$ (Dois mil cruzeiros), a três técnicos em Educação que pelo Estado, sejam postos à disposição da Prefeitura e que serão encarregados da Inspeção do Ensino Municipal.

Art. $8^{\circ}$. Fica o Prefeito autorizado a contratar mediante indicação do Diretor, os progressos que se fizerem necessários para o fiel cumprimento da presente lei.

Art. $9^{\circ}$. As despesas com o funcionamento da Diretoria ora criada deverá correr pela verba destinada ao Ensino Municipal e prevista no orçamento para o próximo exercício.

Art. 10. Fica o Prefeito autorizado a regulamentar os serviços da Diretoria bem como os cargos ora criados.

Art. 11. A presente lei entrará em vigor na data de sua publicação, revogadas as disposições em contrário. (LEI № 648, DE 9 DE JANEIRO DE 1957, p.103-106).

Os propósitos dessa Lei, que criou a Diretoria de Ensino Municipal e deu outras providências, remetem a uma Diretoria de Ensino Municipal subordinada à Secretaria de Negócios Internos e Jurídicos, com um cargo em comissão de Diretor de Ensino Municipal e os vencimentos no valor de $\mathrm{Cr} \$ 6.000,00$ (seis mil cruzeiros), hoje, equivalendo a $\mathrm{R} \$ 2.275,20$ (dois mil duzentos e setenta e cinco reais e vinte centavos). Esse cargo era preenchido por nomeação diretamente ligada ao Prefeito, o que sugere um cuidado da gestão em curso com sua diretoria, particularmente a Diretoria de Ensino.

O ensino era leigo, como já previa as constituições republicanas desde a sua primeira constituição em 1891, e destinado às camadas populares. Essa destinação era garantida por meio de ensino gratuito e suas aulas ministradas, preferencialmente, nos bairros do subúrbio e nas zonas rurais; proibia qualquer discriminação que dificultasse o acesso da criança à escola primária. Tal determinação tentava garantir uma educação pública para todos quando explicita no Art. $4^{\circ}$ que o Executivo criaria e manteria Grupos Escolares e Escolas Municipais, nas regiões indicadas para "objetivar os seus fins".

A Lei no 648/57 prescrevia que a Prefeitura Municipal criasse Grupos Escolares e Escolas Municipais. As Escolas Municipais, na forma da lei, recebiam o nome de Escolinhas. Para viabilizar os trabalhos na Diretoria de Ensino Municipal, foi criado o cargo de Assessor Técnico da Diretoria de Ensino - com vencimentos no valor atual de R\$1.562,62 (hum mil, quinhentos e sessenta e dois 
reais e sessenta e dois centavos) - e cedidos, à disposição, três técnicos em Educação, do Governo do Estado, recebendo uma gratificação, para desempenhar a função de Inspeção de Ensino, no valor atual de $\mathrm{R} \$ 726,80$ (setecentos e vinte e seis reais e oitenta centavos).

As Escolas Municipais, na forma da Lei, receberam o nome de Escolinhas, implantadas como medida de curto prazo, com o objetivo de diminuir os altos índices de analfabetismo. A Figura 1 nos permite conhecer uma sala de aula das Escolinhas

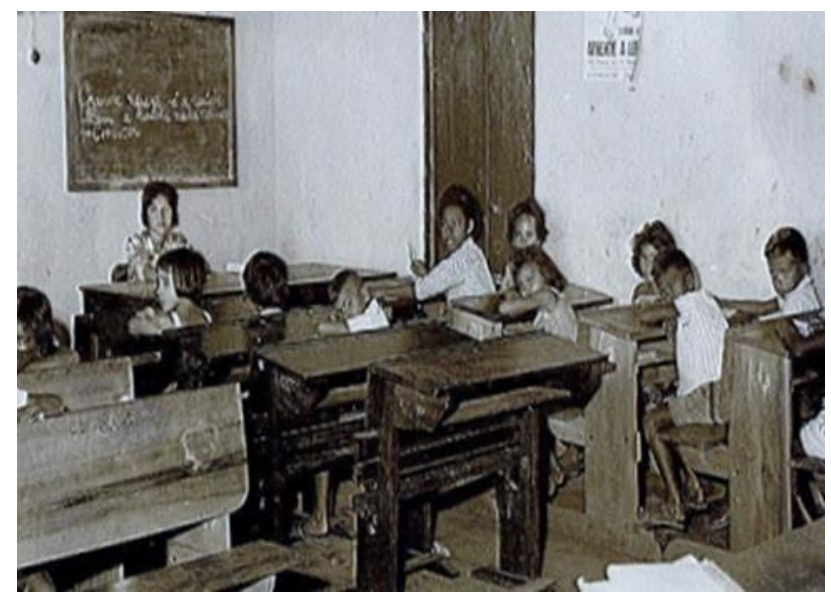

Figura 1: Sala de Aula da Escolinha

Fonte| <https://www.facebook.com/roberto.monte.rn?fref=ts>

Conforme percebemos na Figura 1, a sala era pequena, de piso de cimento queimado, com uma porta trancada e um pequeno quadro em uma das paredes, com carteiras de madeira compartilhadas com outra criança. Observe-se que nessa foto aparecem poucas crianças na sala de aula. Nesse momento histórico, as Escolinhas reduziam-se a uma sala de aula para a realização de um trabalho pedagógico destinado a crianças em idade escolar. Não obstante essa realidade, a educação, de fato, acontecia.

A pesquisa nos possibilitou identificar que a população participava efetivamente do processo de educação da população natalense, disponibilizando lugares institucional ou privado para educar as crianças que não tinham acesso à escola; a Prefeitura Municipal de Natal, em contrapartida, assumia a tarefa de criar Leis e garantir a efetividade da mesma, por meio de um quadro de pessoal e recursos financeiros que pouco a pouco afirmassem a existência de uma rede de ensino municipal da Cidade, com pró-labore para os/as regentes de classe, fornecimento de livros, cadernos, mobiliários e utensílios para a merenda escolar dos alunos (GÓES, 1980).

\section{OS MOVIMENTOS EDUCATIVOS DE NATAL PARA O RIO GRANDE DO NORTE}

Enquanto a educação pública se consolidava na cidade de Natal, capital potiguar, o Governador Dinarte de Medeiros Mariz (1956-1960) empreendia uma reforma educacional para todo o Estado ao regulamentar a Lei no 2.171, datada de 6 de dezembro de 1957, que Organiza e fixa as bases da Educação Elementar e da Formação do Magistério Primário do Estado. Essa lei foi considerada um marco na História da Educação do Rio Grande do Norte, pois tinha por seu objetivo estruturador tanto no que dizia respeito ás maneiras pelas quais o ensino deveria acontecer nos prédios escolares, como elementos definidores para a formação do magistério primário do Estado. 
São ao todo vinte e cinco artigos e que traz em seu Art. 1으 os objetivos gerais dos serviços de educação e cultura do Rio Grande do Norte.

Art. 1ํ- Os serviços de Educação e Cultura do Rio Grande do Norte atenderão:

a) ministrar sempre que possível, educação integral, considerando o aluno não só em função da estrutura escolar, como também do lar e de toda a vida social, tendo em vista os ideais e as tendências democráticas da sociedade moderna;

b) contribuir para a difusão da cultura por meio de serviços apropriados às necessidades da população, desempenhando, sempre que possível, a função do Centro Cultural da Comunidade;

c) observar em cada um dos seus níveis, os métodos mais eficazes de organização, administração, currículo e cursos, procurando sempre adaptá-los às condições locais e aproveitar as experiências bem sucedidas no Estado e em todo o Brasil;

d) prover os serviços especializados que, gradualmente, venham permitir aos indivíduos suprir as deficiências inatas, bem como as do lar e da herança social. (LEI № 2.171, DE 6 DE DEZEMBRO DE 1957, p. 238-239).

Em síntese, o texto da lei preconizava uma concepção de educação integral que buscava "sempre que possível" vincular a escolarização à vida do lar e toda a vida social. Além disso, a lei baseava-se no ideário democrático e de mudança social com métodos de ensino que deveriam contribuir para a adaptação dos estudantes às suas condições locais aproveitando as experiências bem-sucedidas.

Esta preconização da Lei Estadual, poderemos identificar também nos propósitos da Lei no 648, em 9 de janeiro de 1957, que cria a Diretoria de Ensino Municipal e dá outras providências, especificamente no Art. $3^{\circ}$ ao determinar que o "ensino será registrado preferencialmente na periferia suburbana da cidade", e "promover a sua difusão nas camadas populares", considerando a realidade principalmente das crianças e jovens que não tinham acesso e não frequentavam as Escolinhas.

Esta Lei no 2.171/57 também determinava sobre o exercício do Magistério no Estado, condicionando esse exercício aos indivíduos que tivessem formação pedagógica ou, na ausência destes, uma "formação de emergência" deveria ser providenciada para que estivessem aptos a cumprir suas funções pedagógicas.

Art.15 - O magistério Primário será exercido por brasileiros, maiores de 18 anos, em boas condições de saúde física e mental e que hajam recebido preparação conveniente em cursos de formação pedagógica.

$\S 1$ - Na falta de professores diplomados, o Magistério será exercido por elementos locais, para o que será exigido exame de habilitação.

$\S 2$ - Aos docentes não diplomados serão proporcionados cursos determinados em serviço, e formação de emergência, que os habilitam às funções de magistério. 
A responsabilidade institucional desta formação dos professores tanto em serviço para aqueles não diplomados, como para novos professores nos estabelecimentos destinados à formação do Magistério Primário do Estado, está bastante claro no artigo 20:

Art. 20 - Haverá nos estabelecimentos destinados à formação de professores, instituições de nível primário e pré-primário, destinadas a campo de prática, demonstração, experimentação pedagógicas, bem como serviços de assistência e orientação educacional. (LEI № 2.171, DE 6 DE DEZEMBRO DE 1957, p. 245).

Uma evidente preocupação com as maneiras pelas quais essa formação iria acontecer evidenciada em um formato que sugeria uma relação teoria-prática na formação desse futuro magistério ao trazer a obrigatoriedade de escolas de aplicação nas escolas de formação. Nesse texto da Lei no 2.171/57, identificamos que, enquanto a Prefeitura movimentava-se no sentido de criar as Escolinhas, o Governo do Estado do Rio Grande do Norte, estruturava e legalizava as suas ações para os serviços na educação do Estado. Uma busca pela popularização do ensino se espraiava desde a cidade de Natal por todo o território Estadual.

O Governador Dinarte de Medeiros Mariz criou referências legais para o processo de profissionalização do magistério, ao estabelecer que a função no magistério primário, no Rio Grande do Norte, poderia ser exercida legalmente por professores que tivessem dezoito anos de idade, fossem brasileiros, apresentassem boas condições de saúde física e mental e tivessem preparação conveniente em cursos de formação pedagógica.

Reconhecendo que a demanda era muito maior do que a quantidade de professores formados existentes, esta Lei no 2.171/57 já prevê que, na falta de professores diplomados, qualquer cidadão da localidade poderia exercer a função de docência, desde que submetido a um exame de habilitação; os docentes não diplomados eram submetidos a um curso de formação de emergência, após cuja qualificação exerceria a função de magistério. No entanto, a lei determina que, nos estabelecimentos destinados à formação de professores, com nível de primário e préprimário, realizaria a prática, a experimentação pedagógica, os serviços de assistência e orientação educacional.

Desse modo, tendo em vista as políticas educacionais empreendidas tanto no âmbito estadual quanto municipal, Prefeitura de Natal e Governo do Rio Grande do Norte no final da década de 1950, eram parceiros em um trabalho administrativo dinâmico, criando leis que ampliavam e qualificavam a oferta de educação pública para todos, beneficiando, assim, a população.

\section{CRIAÇÕES POPULARES: GINÁSIO MUNICIPAL E A SECRETARIA DE EDUCAÇÃO E CULTURA DE NATAL}

Em agosto de 1958, o Prefeito de Natal, Djalma Maranhão publica a Lei № 835, de 18 de agosto de 1958, p.118-120. Trata-se da criação do Ginásio Municipal de Natal, conforme pode se ver nos seus artigos:

Art. $1^{\circ}$. Fica criado o Ginásio Municipal de Natal que funcionará de acordo com a legislação Federal vigente, subordinado a Diretoria do Ensino Municipal. 
Art. $2^{\circ} \mathrm{O}$ Ginásio Municipal de Natal será instalado depois de preenchidos as formalidades legais perante a Diretoria do Ensino Secundário do Ministério de Educação e Cultura.

Art. $3^{\circ}$ Para regência das cadeiras do aludido Ginásio, o Prefeito Municipal contratará provisoriamente, professores que estejam registrados na Diretoria do Ensino Secundário, até que sejam criados os cargos a serem preenchidos na sua forma da lei.

Parágrafo único - A remuneração dos professores não será inferior a que vigorar para idêntica categoria nos estabelecimentos de Ensino Oficial do Estado.

Art. $4^{\circ} \mathrm{O}$ quadro do pessoal administrativo do Ginásio será organizado de acordo com as normas em vigor e preenchido por servidores já pertencentes ao Município.

Art. $5^{\circ}$ Será nomeado provisoriamente dentre os professores contratados um Diretor, obedecendo às exigências legais que servirá até a instalação do Ginásio.

Art. 6 - Será designado um funcionário para servir de secretário obedecido as formalidades legais.

Art. 70 - O Governo Municipal nomeará dentro de 30 dias uma Comissão composta do Diretor do Ensino Municipal, do Presidente da Associação de Professores do Rio G. Norte e mais três (3) membros de sua escolha, para sob a supervisão do Inspetor Seccional do Ensino Secundário, neste Estado, elaborar em igual prazo o Regimento Interno do Ginásio Municipal de Natal, bem como organizar a documentação exigida para o seu funcionamento.

Art. 8- - A lei orçamentária de 1959, consignará a verba de Cr\$ 2.000,000,00 (dois milhões de cruzeiros) para instalação do Ginásio Municipal de Natal.

Art. 9 - A presente lei entrará em vigor na data de sua publicação, revogadas as disposições em contrário. (LEI № 835, DE 18 DE AGOSTO DE 1958, p.118-120).

Essa lei instituiu o Ginásio Municipal de Natal, que funcionou de acordo com a Legislação Federal, subordinado à Diretoria do Ensino Municipal. Os professores eram contratados, provisoriamente, mas deveriam estar registrados na Diretoria do Ensino Secundário até a criação dos cargos na forma da lei. O quadro de pessoal administrativo era composto pelos próprios servidores pertencentes ao quadro do município de Natal.

A função administrativa de Diretor do Ginásio Municipal de Natal correspondia a um cargo de confiança, tendo, por isso, de ser indicado um professor até o início da instalação do Ginásio. Foi necessário designar uma Comissão com o objetivo de elaborar o Regimento Interno e organizar a documentação necessária para o seu funcionamento. Para a construção do Ginásio Municipal de Natal, foi destinada, por meio da Lei orçamentária de 1959, uma quantia de $\mathrm{Cr} \$ 2.000,000,00$ (dois milhões de cruzeiros) que, em valores atualizados, corresponderiam a $\mathrm{R} \$ \mathbf{7 0 9 . 0 7 4 , 5 2}$ (setecentos e nove mil, setenta e quatro reais e cinquenta e dois centavos).

No Ginásio Municipal de Natal havia aulas destinadas ao Curso Ginasial. A Secretaria de Educação e Cultura, por sua vez, realizava as formações para os professores leigos, capacitando-os por meio do Curso Intensivo para o Magistério Primário Municipal. 
De acordo com o texto do jornal, o Ginásio Municipal de Natal estava localizado na Avenida Rio Branco, 503, Centro. No seu auditório, ocorria o Curso Intensivo para o Magistério Primário Municipal, cuja organização era de competência da Secretaria de Educação e Cultua; o curso tinha como finalidade melhorar o índice técnico das professoras primárias, consequentemente, contribuindo para a melhoria da sua prática em sala de aula ao ensinar as crianças nas Escolinhas.

As duas principais ações legalistas da gestão Djalma Maranhão - a Lei que criou da Diretoria de Ensino e das Escolinhas, em 1958 - garantiram o surgimento de uma rede de educação municipal orientada pela gratuidade do ensino público, direcionada às classes populares e orientada ao combate ao analfabetismo. Medidas que, em nossa análise, caracterizaram esta gestão municipal entre os anos de 1957 e 1964 como marcados por políticas educacionais de caráter eminentemente populares.

No mês de agosto, do ano de 1959, o prefeito Djalma Maranhão se afastou do cargo para concorrer às eleições de 1960 Em seu lugar, a Câmara Municipal de Natal indicou o Presidente dessa Casa Legislativa, o vereador José Pinto Freire, para assumir o Poder Executivo, até a posse do novo prefeito prevista para ocorrer no dia 31.01.1960. O novo prefeito da cidade herdou a política educacional do Prefeito que o antecedeu e criou uma Secretaria de Educação para gerir, estruturar e organizar a educação pública municipal na cidade de Natal: a Secretaria de Educação e Cultura.

Em 19 de dezembro de 1959, ainda ocupando o cargo na Prefeitura Municipal de Natal, o Prefeito José Pinto Freire legaliza, oficialmente, a Secretaria de Educação e Cultura para supervisionar os assuntos educacionais e culturais do município de Natal, por meio da Lei no 988/59, que reorganiza os serviços administrativos da Prefeitura Municipal de Natal e dá outras providências.

Art. $1^{\circ}$. Os serviços administrativos da Prefeitura Municipal de Natal passam a funcionar com a seguinte organização:

I-Gabinete do Prefeito

II - Secretaria de Negócios Internos e Jurídicos

III - Secretaria de Finanças

IV - Secretaria de Viação e Obras

V - Secretaria de Educação e Cultura

$[\ldots]$

Art. $5^{\circ}$. Diretamente subordinada ao Prefeito Municipal fica criada a Secretaria de Educação e Cultura, à qual compete a supervisão de todos os assuntos educacionais e culturais do Município e será composta dos seguintes órgãos:

I-Gabinete do Secretário

II - Diretoria do Expediente

III - Diretoria do Ensino Municipal, à qual estão subordinados:

a) Ginásio Municipal de Natal 
b) Escola Técnica de Comércio Municipal

c) Escolas Primárias Municipais

IV - Diretoria de Documentação e Cultura constituída de:

a) Biblioteca Municipal

b) Museu de Arte Popular

c) Discoteca Municipal.

\section{$[\ldots]$}

Art. 13. A Diretoria de Documentação e Cultura e a Diretoria do Ensino Municipal, atualmente subordinada à Secretaria de Negócios Internos e Jurídicos, ficam transferidas para a Secretaria de Educação e Cultura, ora criada nesta Lei.

\section{$[\ldots]$}

Art. 33. Ficam criados na Diretoria do Ensino da Secretaria de Educação e Cultura 2 (DOIS) Cargos de Inspetores de Ensino, Padrão "S", isolados, de provimento efetivo, ficando extinto o atual cargo de Inspetor de Ensino em Comissão, "S". (LEI № 988, DE 19 DE DEZEMBRO DE 1959).

A Secretaria de Educação e Cultura foi criada num contexto marcado pelo expressivo índice de analfabetismo, produto das poucas escolas para crianças em idade escolar e dos muitos adultos analfabetos, além de um significativo déficit de professores diplomados para atender a uma demanda educacional da população. Foi uma política que se caracterizou como um avanço dentro dos objetivos de estruturação daquilo que se compreendia como organização da educação de um município, pois conforme a Lei anterior, na estrutura da Prefeitura Municipal de Natal, todas as ações da educação municipal deveriam ser gerenciadas pela Diretoria de Ensino Municipal que estava subordinada à Secretaria de Negócios Internos e Jurídicos. Assim, a cidade de Natal, com a criação da Secretaria de Educação e Cultura, é contemplada com uma Secretaria para gerir, estruturar, organizar e operar as demandas educacionais, passando a ser diretamente subordinada à Prefeitura Municipal de Natal.

As implicações reais disso, além de um orçamento próprio, foi mais autonomia para as ações educativas junto à Prefeitura Municipal, fortalecendo-se, assim como uma Secretaria de Educação que iria supervisionar e elaborar as ações nas áreas da educação e da cultura, agregando outros órgãos para desenvolver as práticas educativas e culturais em Natal. Foi com essa ação legal que se formalizou a Secretaria de Educação e Cultura, constituindo-se em um órgão gestor do ensino público municipal, tendo como seu primeiro Secretário o professor Ascendino Henrique de Almeida Júnior.

\section{MATERIALIZAÇÃO DA EDUCAÇÃO POPULAR.}

Djalma Maranhão, tendo se afastado da Prefeitura para candidatar-se na primeira eleição para escolha do Prefeito da cidade, ganha as eleições e no dia 5 de novembro de 1960, na sala Rui Barbosa, localizada no segundo pavimento do Edifício Campullo - local de funcionamento do Poder 
Legislativo Municipal, na Av. Duque de Caxias - Djalma Maranhão tomou posse assumindo o segundo mandato na Prefeitura de Natal (SILVA, 1999).

Djalma Maranhão faz da educação a meta número um de governo. A nova estrutura administrativa da Secretaria de Educação e Cultura se organizou em torno de Diretorias: Diretoria de Ensino, com Omar Fernandes Pimenta; Diretoria de Documentação e Cultura, com Zila Mamede até julho de 1961. O cargo foi ocupado por Mailde Ferreira Pinto Galvão depois de Zila Mamede até o Golpe Militar de 1964, quando todos os Diretores foram destituídos de seus cargos (GÓES, 1980).

Para o cargo de Secretário de Educação foi designado Moacyr de Góes, que havia sido Chefe de Gabinete de Djalma Maranhão em seu primeiro mandato. Este novo panteão foi incumbido da missão de coordenar e viabilizar o programa de governo do Prefeito eleito, dando início a um movimento de educação popular em Natal, cuja meta principal era erradicar o analfabetismo. Os movimentos legalistas de seu primeiro mandato em busca de uma ampliação e qualificação da educação pública municipal começou, com esta estruturação funcional, a dar vistas as ações pedagógicas para à população natalense. Sobre aqueles anos da gestão municipal em relação à educação, Moacyr de Góes escreveu:

Duas grandes coordenadas orientaram e pautaram os serviços da Secretaria de Educação: 1. A educação democraticamente aberta a todos, fiel à problemática brasileira, comprometida com a emancipação do país e do povo, financiada por dinheiro brasileiro; 2. A promoção da Democratização da Cultura. (GÓES, 2000, p. 90-91 grifo do autor).

Políticas públicas criadas pela ação municipal e executadas com financiamento nacional tornaram tais ações educacionais vinculadas a um movimento de educação popular presente em todo o território brasileiro, tornando a pequena cidade do nordeste parte importante deste esforço nacional. Embora os movimentos e campanhas de alfabetização e cultura popular tenham ocorrido em todo o Brasil, na Região Nordeste onde teve origem as mais significativas experiências nessa área de educação e cultura, como: as Escolas Radiofônicas, o Movimento de Educação de Base (MEB), o Movimento de Cultura Popular (MCP), a experiência do método de Paulo Freire. Natal entraria para esse mapa educacional também a partir das Campanhas educacionais do Governo Djalma Maranhão.

A Secretaria de Educação e Cultua estava comprometida, em suas bases históricas de fundação, com uma educação fundamentada nos princípios da educação popular, associada aos valores de desalienação e de libertação do povo, integrando crianças, jovens e adultos a sua comunidade, com a garantia de acesso para todos os que quisessem frequentar a escola e de sentir e viver a cultura de seu povo na promoção da democratização da cultura, com ênfase na Cultura Popular. Tais compromissos expressavam a completa identificação com uma educação popular para todos.

Mas como cumprir tais metas com os poucos recursos da administração municipal? Particularmente, a falta de recursos para construir escolas públicas municipais para crianças, jovens e adultos, ia de encontro à meta de erradicar o analfabetismo. O Secretário de Educação Professor Moacyr de Góes recorre, então, aos membros do Comitê Nacionalista do bairro das 
Rocas que se constituíam como núcleos de organização popular para discutir em torno de algumas bandeiras políticas em nível internacional, nacional e local. (GOÉS, 1980). Um fórum político foi convocado naquele ano de 1961 para discutir e viabilizar propostas que solucionassem o problema gerado por dois fatores: por um lado, o alto índice de analfabetos; por outro, a falta de recursos da Secretaria de Educação e Cultura para construir escolas que atendessem a demanda de alfabetizar crianças, jovens e adultos.

Em meio a esse processo político - transformador - na sala do Grupo Escolar do professor Acrísio Freire, no início de fevereiro de 1961 - aconteceu uma reunião que contou com a participação de aproximadamente cinquenta pessoas. A pauta da reunião era muito clara: como construir escolas com os poucos recursos que esse grupo dispunha para o tanto que precisavam. A sugestão veio de um partícipe anônimo presente nesta reunião histórica em construir salas no formato de Acampamentos de palha de coqueiro, já que não havia recursos financeiros na Prefeitura para arquitetar escolas de alvenaria. Após longa discussão, sobre como seria a estrutura dessa construção - notadamente em relação à construção das escolas - foi votada e aprovada por todos os membros do Comitê Nacionalista das Rocas a ampliação das Escolinhas - que não deixariam de existir - além da construção dos Acampamentos Escolares em forma de galpão coberto com palha de coqueiro.

Essa sugestão teve o respaldo do Prefeito Djalma Maranhão e, no dia 23 de fevereiro de 1961, foi levada a cabo, oficialmente, sob o nome de Campanha de Erradicação do Analfabetismo com o bairro das Rocas como o primeiro bairro a ser contemplado pelo plano elaborado pela Secretaria de Educação e Cultua. De acordo com SOARES e FÁVERO (2009), "o nome da Campanha nasceria de uma reportagem da imprensa, quando o jornalista Expedito Silva, noticiando o programa de educação popular que se iniciava em Natal, afirmava que "de pé no chão também se aprende a ler". (SOARES; FÁVERO, 2009, p. 140). O que significava, metaforicamente, que todos teriam acesso à escola sem a obrigatoriedade de fardamento e até sem os calçados nos pés, esse movimento objetivava a ampliação da rede de escolas municipais em Natal, permitindo o acesso a educação popular por crianças, jovens e adultos. Essa campanha que assumia a denominação De Pé no Chão Também se Aprende a Ler, tinha como símbolo a imagem que segue:

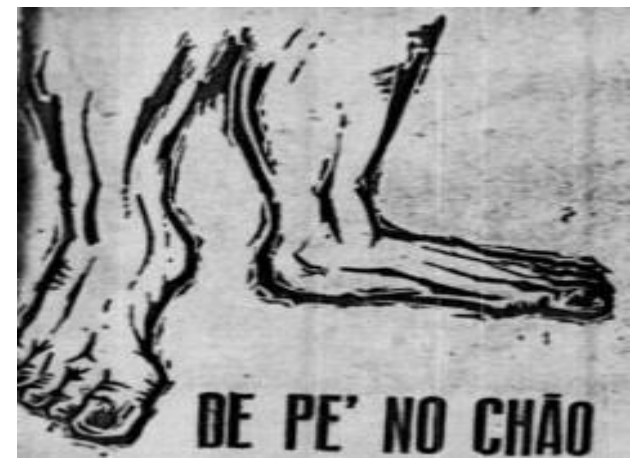

Figura 2: Símbolo da Campanha

Fonte | <https://www.facebook.com/roberto.monte.rn?fref=ts>

A representação de "dois pés" descalços, pintados pelo artista plástico Newton Navarro, se constituiu no símbolo ou logomarca da Campanha De Pé no Chão Também se Aprende a Ler. Se bem lembrarmos, como já foi demonstrado aqui neste artigo, uma das primeiras ações desta liderança política foi à criação da Lei no 2.171, com o intuito de organizar e fixar as bases da 
Educação Elementar e da Formação do Magistério Primário do Estado, garantia que uma dessas bases seria está "nele proibida quaisquer discriminações tendentes a lhe impedir ou dificultar o acesso". (LEI № 648, DE 9 DE JANEIRO DE 1957, p.103-106). Um ciclo de continuidade administrativa, envolvendo dois mandatos, se fechava ao fim de quatro anos para garantir que a Lei se fizesse expressar numa vivência prática.

O início da campanha foi noticiado nos principais jornais da cidade e, particularmente, o jornal Folha da Tarde, dirigido pelo próprio Djalma Maranhão. Participava como "integrantes do comando" o Secretário de Educação professor Moacyr de Góes e os integrantes do Grupo de Trabalho de Educação popular. Na reportagem, a Campanha de Erradicação do Analfabetismo, lançada pelo Prefeito Djalma Maranhão, colocava seu objetivo de criar uma rede municipal de escolas em Natal para oferecer às classes populares a partir da campanha De Pé no Chão Também se Aprende a Ler e seus Acampamentos Escolares. Em seguida é possível ver um dos acampamentos, o Acampamento Escolar das Rocas localizado no bairro das Rocas, que atendia a crianças, jovens e adultos em processo de alfabetização.

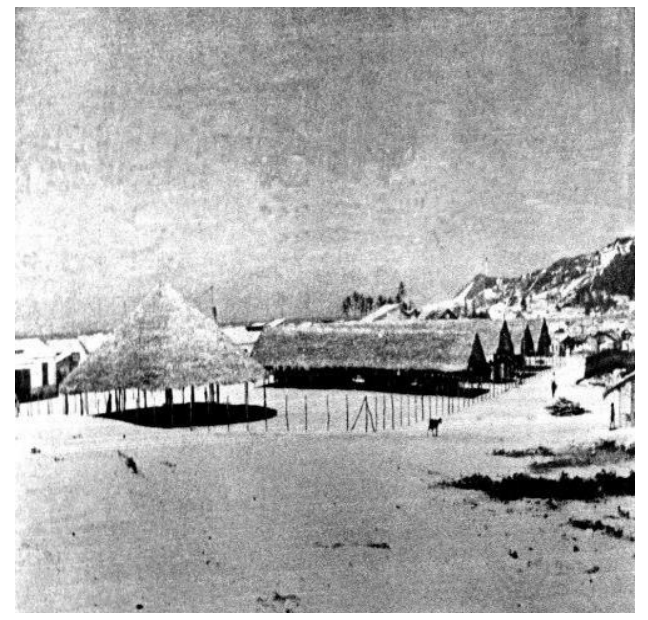

Figura 3: Acampamento Escolar/Rocas

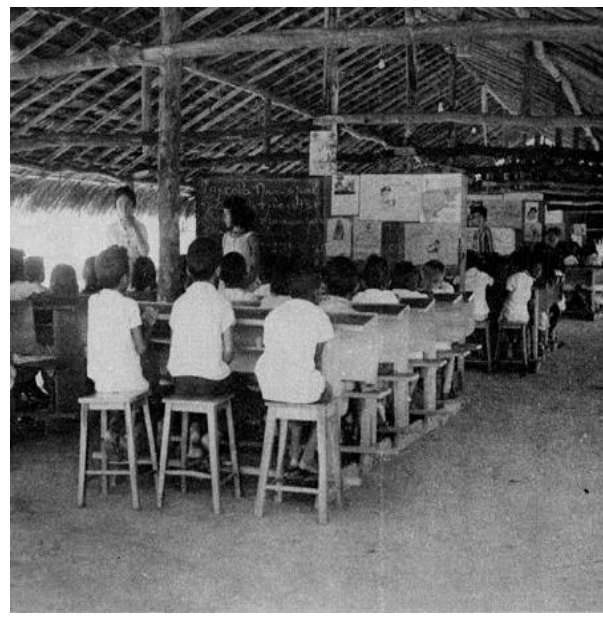

Figura 4| Acampamento Escolar/Rocas Fonte | <https://www.facebook.com/roberto.monte.rn?fref=ts>

Conforme pode se observar o Acampamento Escolar tinha a estrutura das moradias dos pescadores da região com um teto construído com palha de coqueiro em chão de barro batido, com duas quedas d'água. A equipe que assegurava a operacionalização de um Acampamento Escolar era integrada por um diretor, regentes de classe ou monitoras - chamadas professorinhas pela população local -, e as recreadoras. Era iluminado com lâmpadas a álcool no formato de galpões de $30 \mathrm{~m} \times 8 \mathrm{~m}$, em sua forma retangular e um pavilhão circular destinado às festas culturais do bairro e das festividades da escola, as aulas de recreação infantil, apresentações de teatro e autos folclóricos (GÓES, 1980), numa estreita relação com a cultura popular e a cultura escolar.

A construção de um galpão representava um ganho político e educacional para a cidade e, ao mesmo tempo, baixo custo para a Secretaria de Educação e Cultua. Para construir um galpão, eram necessárias 2.000 (duas mil) palhas de coqueiro, 20 (vinte) quilos de prego, madeira, piso de barro batido e mão de obra de construção. Eles totalizavam $\mathrm{Cr} \$ 95.00,00$ (noventa e cinco mil cruzeiros), que, atualizando para nossa moeda, corresponderia a $\mathrm{R} \$ 10.232,76$ (dez mil duzentos e 
trinta e dois reais e setenta e seis centavos). Um galpão tinha quatro salas de aula e o preço da construção de uma sala era de CR\$23.750,00 (vinte e três mil, setecentos e cinquenta cruzeiros) (SOARES; FÁVERO, 2009). Esse orçamento corresponde aos custos vigentes no ano de 1962. Esse valor na moeda atual corresponde a $\mathrm{R} \$ 2.558,19$ (dois mil, quinhentos e cinquenta e oito reais e dezenove centavos). Além do baixo custo de construção e manutenção, a ausência de muros e paredes, não enclausuravam as crianças, ao contrário, com essa proposta as salas não perdiam sua conectividade com o vento, nem com a vida do lugar. Não foi possível conhecer se havia essa intencionalidade, mas era uma realidade perceptível pelas tantas imagens que pudemos encontrar dos Acampamentos Escolares do Governo Djalma Maranhão.

Os princípios pedagógicos que orientavam a ação educativa na escola, nos fins dos anos de 1950 e início de 1960, consistiam em uma educação centrada na criança, no cuidar, na atividade espontânea e no respeito dos professores educadores, ao desenvolvimento da criança. A recreação infantil nos Acampamentos Escolares era realizada, regularmente, com as crianças e constava de danças, cantigas de roda, pular corda, jogos, brincadeiras e folguedos populares. Tais atividades recreativas contribuíam para diminuir a evasão escolar, estimulando, na criança, o interesse pela escola, a valorização do seu conhecimento, integrando escola e a criança na sua realidade.

As políticas de educação da administração Djalma Maranhão iam gradativamente, e por força de processos históricos, consolidando as políticas de educação popular. Tais políticas, em razão da própria dimensão conceitual do termo, foram incluindo mais pessoas no processo de implementação e reorganização política da cidade, transformando-a em uma cidade educadora com muitas dimensões do mesmo processo acontecendo pela cidade. Dialogando com a comunidade escolar e a não escolar, população e governo, se consagraram como grandes responsáveis por um processo educacional que, mesmo em sérias e precárias condições financeiras, conseguia alfabetizar e educar politicamente toda uma cidade, construindo, em sua essência, uma cidade educadora.

\section{A EDUCAÇÃO POPULAR PASSEIA PELAS RUAS DE NATAL}

A Lei no 988/59, que reorganiza os serviços administrativos da Prefeitura Municipal de Natal e dá outras providências anteriormente citada, também instituiu a Diretoria de Documentação e Cultura (DDC), que fazia parte da estrutura da Secretaria de Educação e Cultura, e a ela vinculou a Biblioteca Municipal, o Museu de Arte Popular e a Discoteca Municipal.

A DCC contribuiu para desenvolver um trabalho educativo relativo às manifestações da cultura popular, dinamizando toda a cidade de Natal e fortalecendo os eventos realizados na e pela Campanha De Pé no Chão Também se Aprende a Ler. Esse trabalho educativo fundamentava-se no respeito às origens culturais da população de Natal revitalizando, principalmente, a cultura popular nos bairros da cidade. De acordo com Góes (1980) “Era política expressa da Secretaria de Educação e Cultura vincular o Acampamento às organizações populares e lideranças culturais mais expressivas do bairro onde se localizava". (GÓES, 1980, P.69).

Como prática educativa e cultural das políticas municipais de educação popular para todos, foi realizado o I Seminário de Estudos dos Problemas de Educação e Cultura do Município de Natal, 
no ano de 1961. Este Seminário foi uma realização da Prefeitura, por meio da Secretaria de Educação e Cultura, sob a coordenação do Secretário de Educação Moacyr de Góes e do Diretor do Ensino Omar Fernandes Pimenta, planejado e organizado pelos funcionários da Secretaria de Educação e Cultura. Todos dentro da Secretaria se empenharam na realização do evento que procurou mostrar que Natal, tinha um movimento próprio, um processo político educacional e cultural singular e buscava suas definições com a participação da sua população, construindo uma cidade educadora e com a participação de todos.

Fazia parte da programação do I Seminário de Estudos dos Problemas de Educação e Cultura do Município de Natal um ciclo de conferências abordando temas relacionados à realidade de Natal no ensino e na cultura. Segundo Góes (1980):

O Seminário procurou fazer um levantamento da realidade educacional e cultural da cidade. Sua proposta era a de uma ampla pesquisa e questionamento, dividida em diversos planos, entregues a especialistas em cada assunto. (GÓES, 1980, p.92).

Por meio do jornal Folha da Tarde de 23 de fevereiro de 1961 identificamos que o I Seminário foi promovido pela Secretaria de Educação e Cultua e teve início no dia 6 de março de 1961. O Seminário procurou fazer um levantamento das realidades educacional e cultural da cidade e foi estruturado em quatro fases. Sua programação se constituiu de um ciclo de conferências a cargo de professores potiguares, conhecedores dos problemas educacionais da região, onde cada professor era responsável por uma temática. De acordo com Góes (1980), os temas e os especialistas foram os seguintes:

Região e educação (Luis da Câmara Cascudo); Escola natalense e comunidade (João Wilson Mendes Melo); A escola natalense, o Humanismo e a técnica (Hélio Galvão); A escola particular em Natal (Carmem Pedroza); A escola pública em Natal (Luis Ignácio Maranhão Filho); A escola confessional em Natal (Padre Manoel Barbosa); Atividades culturais extraclasses em Natal (Alvamar Furtado); Administração escolar em Natal (Max da Cunha Azevedo); A escola natalense e a orientação educacional (Elsa Sena); A fixação do aluno à escola primária em Natal (Maria Alexandrino Sampaio); A reforma do ensino primário do Rio Grande do Norte em Natal (Lia Campos); A escola para excepcionais em Natal (Severino Lopes); O ensino secundário em Natal (Ascendino Henrique de Almeida); $O$ ensino comercial em Natal (Ulisses de Góes); $O$ ensino industrial em Natal (Irineu Martins); O ensino normal em Natal (Chicuta Nolasco Fernandes); $O$ ensino doméstico em Natal (Noilde Ramalho); O ensino universitário em Natal (Edgar Barbosa); A escola natalense, a arte tradicional e a cultura popular (Veríssimo de Melo); A escola natalense, bibliotecas e museus (Zila Mamede); A escola natalense e a música (Américo de Oliveira Costa); A escola natalense e as artes plásticas (Newton Navarro); A escola natalense, a literatura e as ciências (Núbio Borges); Uma experiência no setor de educação em Natal (Grimaldi Ribeiro). (GÓES, 1980, p.92-93).

Assim, ao considerar a educação como prioridade, o governo tentava erradicar o analfabetismo, ao mesmo tempo em que oferecia uma educação para todos implicando toda a população no projeto concebido pela equipe da Secretaria de Educação e Cultura no segundo mandato do governo de Djalma Maranhão. Por isso, já não bastavam as Escolinhas porque elas 
não atingiam as áreas mais afastadas e menos favorecidas socioeconomicamente. $O$ governo popular precisava ser para todos e as ações da Diretoria de Documentação e Cultura (DDC), sob o comando de Mailde Ponto Galvão foram o complemento ao projeto inicial de escolarização para todos na direção de uma educação para todos.

O Programa da DDC objetivava despertar a consciência do povo, desenvolvendo um trabalho de divulgação do folclore, da música tradicional e dos folguedos populares (GÓES, 2000). O Programa realizava suas atividades culturais na Galeria de Arte, no Museu de Arte Popular, nas Bibliotecas Populares, no Teatrinho do Povo e nas Praças de Cultura. Essas Instituições Culturais criadas durante o Governo Djalma Maranhão, marcaram a história cultural da cidade ao revitalizar, naquele momento histórico, as manifestações da cultura popular nos quatro cantos da cidade.

A instalação de palanques para apresentações culturais dos grupos e conjuntos folclóricos nos bairros de Natal foi uma das ações do Programa de Democratização da Cultura. As ruas eram ornamentadas com alegorias próprias numa proposta de diversão livre para o povo, apresentando danças e cantos com a participação ativa da população pelas ruas da cidade de Natal. A participação da população, nos anos de 1959 a 1964, foi muito intensa e dinâmica, com a coexistência de dezoito conjuntos folclóricos em Natal de várias dessas manifestações culturais populares. Eram 04 conjuntos de Boi Calemba, 04 conjuntos de Bambelô, 04 conjuntos de Congo, 02 de Pastoris , 01 conjunto de Fandango, 01 de Lapinha e 03 conjuntos de danças antigas: Araruna, Camaleão e Chegança (SOARES; FÁVERO, 2009).

O trabalho desenvolvido pela Diretoria de Documentação e Cultura (DDC) acontecia numa relação dialógica entre a instituição pública municipal e a população, dinamizando a cultura popular exatamente nos bairros onde as crianças, jovens e adultos começavam a ler e a escrever. Essa relação da escolarização com a educação popular também podia ser percebida nas Praças de Cultura, com apresentações teatrais e publicações de livros. Abaixo um vislumbre do movimento de pessoas nessas apresentações:

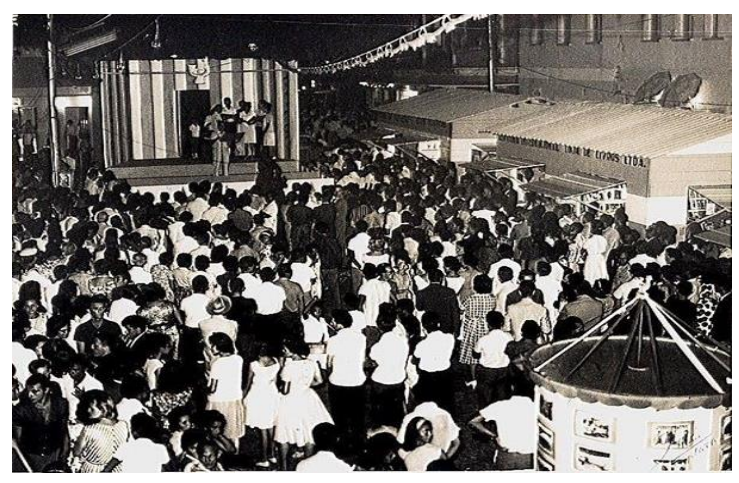

Figura 5| Praça de Cultura

Fonte | <https://www.facebook.com/roberto.monte.rn?fref=ts>

As Praças de Cultura com barracas de madeira e os palanques se constituíam em lugares educativos para a realização de feira de livros, de discos, de artes plásticas, com as publicações dos poetas e a venda de literatura de cordel, promovendo o contato direto do escritor com os leitores em diálogo permanente. As Praças eram vida em movimento e, em cada fragmento do tempo no cotidiano da cidade de Natal, era um lugar que educava e fazia a sua história com a presença de pessoas que, depois, seguiam seus caminhos em direção a outros afazeres. 
As políticas educacionais iniciadas pela prefeitura em 1957 a partir de mecanismos legais ganharam contornos de políticas públicas de educação popular a partir das ações empreendidas pela Secretaria entre 1961 e 1963. Foi um tempo em que a efervescência político, educacional e cultural da cidade dimensionou pela primeira vez a possibilidade de uma cidade educadora em atenção prioritária às classes populares, suas demandas e manifestações. Mas, esse caminho trilhado foi interrompido violentamente pela ditadura que se instaurou no país.

\section{A DITADURA CIVIL E MILITAR E O DESMONTE DA POLÍTICA DE EDUCAÇÃO POPULAR EM NATAL}

A partir de 1964 o quadro político do Brasil mudou, se instaurava uma ditadura civil e militar, essa nova configuração considerava as ações implementadas pelo Prefeito Djalma Maranhão e as atividades educativas desenvolvidas pela equipe da Secretaria de Educação e Cultura - especificamente as relacionadas com a Campanha De Pé no Chão Também se Aprende a Ler -, como ações de caráter subversivo, vinculadas ao comunismo e contrárias ao programa político-econômico brasileiro, que se instaurava em 1964. Portanto, tudo o que se tinha feito em Natal, deveria ser coibido, vetado e sempre que possível exterminado.

Nesse sentido, é importante apresentar as considerações de Germano (2008) sobre a Ditadura Militar, que assim afirma:

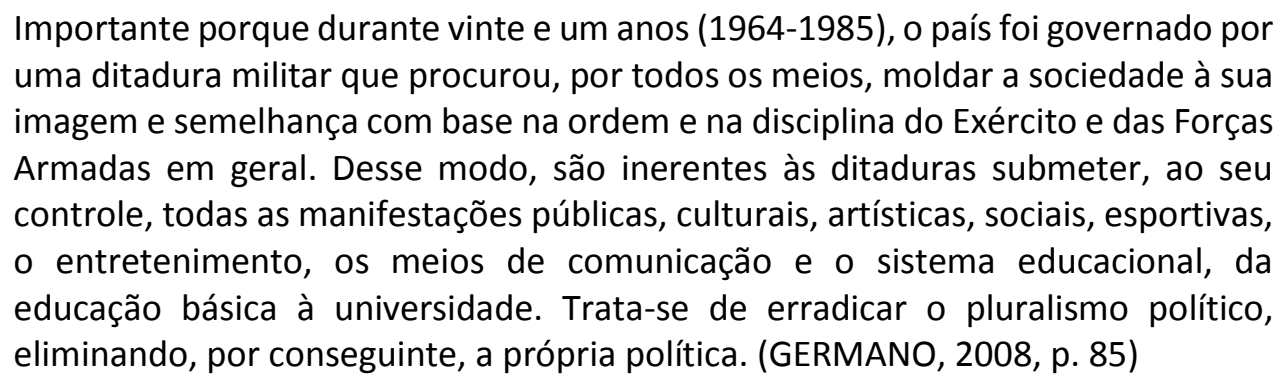

Nesse texto, identificamos elementos que explicam porque a experiência vivenciada em Natal deveria ser extinta, e muitas pessoas assassinadas, pois a partir de 1964, com o Golpe Civil e Militar, a população civil deveria ser afastada das definições das políticas públicas a serem implementadas na cidade de Natal.

Instaurava-se uma noção de Estado completamente desvinculada do que foi experimentado pela gestão e população natalense nos anos imediatamente anteriores ao Golpe de 1964. O Golpe Civil e Militar no Brasil nos remeteu à definição de Estado elaborada por Hobbes (2009).

Damos o nome de Estado por aquisição àquele em que o poder soberano foi adquirido pela força. E tal poder é assim adquirido quando os homens, individualmente ou em grande número e por pluralidade de votos, por medo da morte ou do cativeiro, autorizam todas as ações daquele homem ou assembleia que tem em seu poder vidas e sua liberdade. (HOBBES, 2009, p 144). 
A cidade de Natal, como parte da Federação Brasileira, passou a ser governada pelas Forças Armadas que exercia todo o poder numa versão ainda mais centralizadora e autoritária, pois que aquela situação não representava a vontade individual ou de um grande número de pessoas, nem estavam eles autorizados a realizarem ações em nome deles. Esse quadro não respeitava a vontade daqueles que aqui moravam, nem estavam interessados em pactos com a população, seus desejos, objetivos, vontades ou necessidades. Algo diferente e sombrio se espraiava por aquele litoral que estava a experimentar outra perspectiva social de gestão e educação municipal. E todas as ações foram virando poeira da história na medida em que seus membros eram exilados e seus projetos queimados.

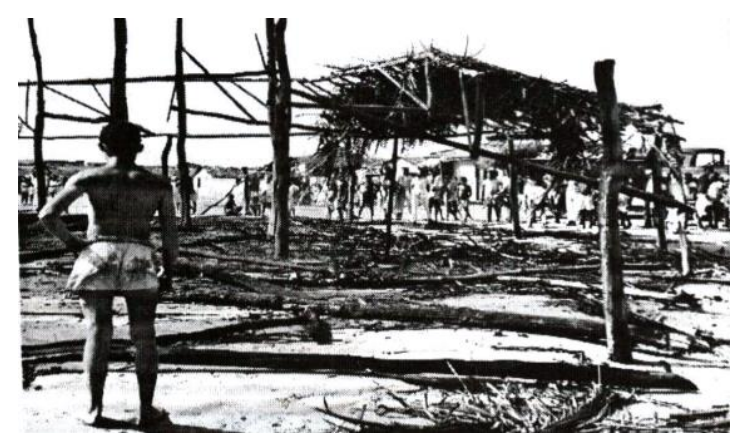

Figura 6| Acampamento Escolar queimado Fonte | Cortez (2005)

Essa Figura 5 apresenta o Acampamento Escolar do bairro das Rocas incendiado. A destruição de um projeto educativo popular e para o povo voltado em última análise a construção e transição de consciências. É de se perguntar até onde teria ido esse projeto educativo que foi destruído ainda em sua infância com apenas três anos de operação. Mas, essa é uma resposta que nem se pretendeu com essa pesquisa nem será possível responder. Retomar é lugar que não existe na história política do Brasil, quando nos referimos ao Golpe de Estado de 1964.

Essa fotografia traduz para nós o extermínio de um movimento educacional popular humanizante, mesmo que seus resultados ainda não tenham cessado de ressoar enquanto ruínas em uma Secretaria de Educação, criado, dialogicamente, para organizar e estruturar um processo educacional de uma cidade que estava disposta a construir, com o poder público municipal, um movimento educacional popular em que todos os cidadãos fossem alfabetizados. Talvez as pessoas estivessem vivenciando uma retomada de si, ou uma descoberta de si, por meio da valorização das pessoas que os educavam, e que teciam, com arte, a reconstrução da cidade. Aos poucos, Natal se transformou em uma cidade educadora.

As Forças Armadas, incorporando a definição de Estado de Hobbes, como detentora do poder adquirido - não por voto ou assembleia, mas por medo da morte, do cativeiro e, como autoridade maior - utilizou-se da força e de todos os meios para garantir a ascensão dos militares ao poder. Esse movimento teve como uma de suas consequências o extermínio daquilo que a população de Natal, em diálogo e participação popular, construiu na educação e na cultura, por meio da Prefeitura Municipal de Natal e da Secretaria de Educação e Cultura, ao definirem as políticas de educação popular para a cidade.

Natal, em 1964, havia perdido, por força de fuzis apontados para a população, a efervescência dos movimentos sociais e o colorido da educação popular para todos. Sobrou a 
realidade trazida pelo Ato Institucional $\mathrm{n}^{\circ} 1(\mathrm{Al}-1)$, com poderes constituintes, ditando normas, instaurando Inquéritos Policiais Militares (IPMs).

$\mathrm{Na}$ cidade educadora onde a população estava aprendendo a ler, a cassado o direito a pronunciar palavras; era o tempo quando se violentavam os direitos políticos de líderes partidários, sindicalistas, professores, estudantes, militares e intelectuais; aposentadoria forçada de funcionários públicos civis e militares determinando os destinos da vida da população, conforme podemos constatar por meio da descrição de Galvão (2004, p. 41), "[...] jipes e caminhões do Exército já eram vistos transportando militares armados com metralhadoras e fuzis para os pontos da cidade considerados por eles, como estratégicos".

No dia 2 de abril de 1964, às 15 horas, nas dependências da Prefeitura Municipal de Natal, o Prefeito Djalma Maranhão foi preso por patrulha do Exército em seu gabinete. Segundo relato de Galvão (2004), testemunha do momento da invasão na Prefeitura Municipal de Natal quando Djalma Maranhão foi preso e logo após, ao ser levado preso para o Quartel General do Exército, recusou negociar com as autoridades militares, ele:

Quis permanecer só e sozinho estava quando, minutos depois, os militares vieram prendê-lo. [...]

O prefeito foi conduzido ao Quartel-General do Exército [...].

O Coronel Ihe propôs que renunciasse ao cargo de prefeito e, em troca, teria assegurada a liberdade. $O$ prefeito recusou em nome da honra e do povo que 0 elegeu; foi, então, levado preso, incomunicável, para uma cela do quartel $16^{\circ} \mathrm{RI}$. (GALVÃO, 2004, p. 49).

No relato de Galvão (2004), o Prefeito Djalma Maranhão estava só, sem a presença das pessoas que haviam contribuído para combater o analfabetismo e revitalizar a cultura popular em Natal. Conduzido ao Quartel General do Exército, recusou a renunciar o cargo de Prefeito Municipal mesmo tendo a liberdade como proposta. Mas a decisão do Prefeito Djalma Maranhão teve consonância com os seus valores humanos e em respeito à população que o elegeu. Assim, foi levado preso, ficando incomunicável em uma cela no quartel do 16 을 de privação da liberdade aconteceu também com as lideranças políticas, professores, operários, sindicalistas, estudantes e intelectuais, todos conduzidos para o 16ㅇ Batalhão de Infantaria Motorizado ITAPIRU.

No dia 3 de abril de 1964, o Jornal Diário de Natal divulgava a reportagem em que evidenciava - além da prisão efetuada por patrulhas do Exército no dia anterior - o impeachment do Prefeito Djalma Maranhão e do vice-prefeito Luiz Gonzaga dos Santos, que foi decretado pela Câmara Municipal de Natal em sessão secreta, nada constando em seu Livro de Atas (GERMANO, 1989).

Natal passou a ser uma cidade em que a democracia foi proibida: fortalecia o Golpe Civil e Militar. Nesse contexto, muitos jovens foram presos e assassinados; entre eles, estudantes no início de suas vidas que sonhavam e acreditavam num país alfabetizado e com menos desigualdade social. 
As fontes permitiram perceber que toda a trajetória da educação popular era um movimento que implantava instituições educativas como lugares de diálogos, discussões, reflexões, de participação popular, de democratização da cultura e de produção de novos conhecimentos, garantindo e promovendo um ambiente acolhedor e propício à elaboração e à realização de propostas que atendessem aos interesses, problemas e necessidades daqueles que dela faziam uso, bem como da comunidade a que pertenciam. Esse entendimento permitiu identificar e analisar os fatos que marcaram o contexto educacional sobre as políticas de educação popular em Natal.

Ademais, possibilitou compreender que toda a jornada da política de educação popular em Natal, no período estudado teve como base uma prática educativa democrática, sustentada em três pilares: a) participação e implicação da população natalense; b) construção e reconstrução das práticas pedagógicas priorizando, em seus programas de ação, a alfabetização para todos; c) democratização da cultura. Esse processo histórico transformou Natal numa cidade educadora.

\section{REFERÊNCIAS}

1. ARISTÓTELES. Política. Tradução Nestor Silveira Chaves Rio de Janeiro: Nova Fronteira, 2011.

2. CORTEZ, Margarida de Jesus. Memórias da Campanha "de pé no chão se aprende a ler": reflexões sobre a prática pedagógica de ontem e de hoje. Natal: EDUFRN, 2005.

3. FREIRE, Paulo. Educação como prática da liberdade. 14. ed. Rio de Janeiro: Paz e Terra, 2011.

4. GALVÃO, Mailde Pinto. 1964: aconteceu em abril. 2. ed. Natal: EDFURN, 2004.

5. GERMANO, José Willington. Lendo e aprendendo: a campanha de pé no chão. 2. ed. São Paulo: Autores Associados; Cortez, 1989.

6. O Ordem e progresso: o discurso político sobre a educação no Brasil autoritário. Revista Educação em Questão, Natal, v. 32, n. 18, p. 85, maio/ago. 2008.

7. GINZBURG, Carlo. Mitos, emblemas, sinais. São Paulo: Companhia das Letras, 1989.

8. __ _ _ O queijo e os vermes. São Paulo: Companhia das Letras, 2006.

9. ___ Andarilhos do bem. São Paulo: Companhia das Letras, 2007.

10. GÓES, Moacyr. De pé no chão também se aprende a ler: 1961-64: uma escola democrática. 2. ed. São Paulo: Cortez, 1980.

11. _. (Org.). 2 livros de Djalma Maranhão no exílio. Natal, RN: Prefeitura Municipal do Natal: Artprint, 2000.

12. _. Educação Popular, Campanha De Pé no Chão Também se Aprende a Ler, Paulo Freire \& Movimentos Sociais Contemporâneos. In: ROSAS, Paulo (Org.). Paulo Freire Educação e Transformação Social. Recife: Editora Universitária da UFPB; Centro Paulo Freire de Estudos e Pesquisas, 2002

13. HOBBES, Thomas. Leviatã, ou, matéria, forma e poder de um estado eclesiástico e civil. São Paulo: Martin Claret, 2009.

14. LEITE, José Evangilmárison Lopes. Em nome da ordem: a prefeitura municipal de Natal como espaço de espaço da subversão. Dissertação (Mestrado em Educação) - Centro de Ciências 
Sociais Aplicadas, Universidade Federal do Rio Grande do Norte, Natal, 2008.

15. NATAL (Cidade). Lei no 648 de 9 de janeiro de 1957. Cria a Diretoria de Ensino Municipal e dá outras providências. Natal, 1957.

16. NATAL (Cidade). Lei no 988 de 19 de dezembro de 1959. Reorganiza os serviços administrativos da Prefeitura Municipal de Natal e dá outras providências. Natal, 1959.

17. RIBEIRO, Iza Paula Zacarias. As praças da cultura no governo Djalma Maranhão (1960-1964). Dissertação (Mestrado em História) - Centro de Ciências Sociais Aplicadas, Universidade Federal do Rio Grande do Norte, Natal, 2008.

18. SOARES, Leôncio; FÁVERO, Osmar (Orgs.). Primeiro encontro nacional de alfabetização e cultura popular. Brasília: MEC; UNESCO, 2009. 